\title{
ITS Community Service Program as A Medium to Empower Community in Facing the Era of Industrial Revolution 4.0
}

\author{
Hermanto $^{1}$
}

\begin{abstract}
As agents of change, students are required not only to have knowledge and expertise in their fields, but they must also be ready to be in the community to implement the knowledge and skills they have, help solve real problems faced by the community or provide knowledge and skills to the community so they can lead better life. To meet these goals, Institut Teknologi Sepuluh November (ITS) conducted community service program $(\mathrm{KKN})$ for students to communities. In line with ITS students' background, the themes of KKN were related with technology and its applications, so that the KKN activities in the community were also inseparable from the theme of technology and its application. Thus, KKN ITS is the right medium to help the community in facing the current era of the industrial revolution in which technology and its application serve as its core.
\end{abstract}

Keywords: ITS Community service program, industrial revolution, technology and its application, community empowerment

\section{INTRODUCTION}

Community Empowerment Service Program (KKN) is one of the activities in higher education that is held based on the 1945 Constitution and Law Number 2 of 1989 concerning the National Education System in conjunction with Government Regulation of the Republic of Indonesia Number 60 of 1999 concerning Higher Education. Education is basically a systematic process of human maturity and independence, so that they are ready to live their lives responsibly. To live life responsibly means being brave to make wise decisions while at the same time daring to bear the consequences.

For the sake of this noble ideal, education in Higher Education is carried out by equipping and developing religiosity, qualification, skills, sensitivity and love of students towards the glorification of the lives of humankind in general and Indonesian society in particular. The provisioning and development of these matters are summarized in the Tri Dharma of Higher Education, namely Education and Teaching, Research, and Community Service. The Law of the Republic of Indonesia Number 20 of 2003 concerning the National Education System in article 20 paragraph 2 states: "Higher education is obliged to carry out education, research, and community service". comArticle 24 paragraph 2 states: "Universities have the autonomy to manage their own institutions as centers for the administration of higher

${ }^{1}$ Hermanto, Departement of Development Studies, Institut Teknologi Sepuluh Nopember, Surabaya, 60111. E-mail: hermantoaku@gmail. education, scientific research, and community service." The three aspects of the Tri Dharma of Higher Education are carried out in balanced, harmonious and integrated proportions with the hope that someday college graduates can become knowledgeable human beings, adequate in their respective fields, able to conduct research, and willing to devote themselves for the benefit of humanity in general and Indonesian society in particular.

To practice knowledge and apply the results of research conducted by the academic community, it needs a supportive media. KKN is a compulsory intracuricular activity that combines the implementation of the Tri Dharma of Higher Education with the method of providing learning experiences and work to students, in community empowerment activities. $\mathrm{KKN}$ is also a vehicle for the application and development of science and technology, carried out outside the campus in time, work mechanism, and certain requirements. Therefore, $\mathrm{KKN}$ is directed to ensure the relationship between the academic-theoretical world and the empirical-practical world. Thus there will be a synergistic interaction, mutual acceptance and giving, teaching, loving, and caring for between students and the community.

Thematic KKN is a $\mathrm{KKN}$ whose program orientation is focused on certain fields in accordance with social issues and the direction of development policies organized by certain regional governments (Regency/City) [1].

\section{METHOD}

This research is descriptive in nature trying to describe types of students' community service activities based on the title of the activity program that contains correlations with elements of the industrial revolution 4.0. represented by the key words related to it. Data is collected from the list of titles of KKN activity obtained from LPPM ITS.

Although ITS thematic KKN has been held for three semesters since Odd semester 2018, for the first two semeters, Odd and Even semester 2018/2019, the titles used by each group were the same, in accordance with the big theme of KKN namely "Technology and Its Applications". Therefore, this research did not take the title for that semester as the object of research.

In the Odd semester 2019/2020, each of 62 KKN groups had to propose different titles which then become the object of this research. The list of titles was then analyzed and further grouped according to the model of KKN activities, namely activity model A, activity model $\mathrm{B}$, activity model $\mathrm{C}$, and activity model $\mathrm{D}$. The purpose of 
this grouping is to find out how many activity titles for each activity model.

Next, after grouping the titles according to the activity model, the researcher looked for key words from the titles related to the key words relevant to the industrial revolution 4.0. The linkages between the keywords in the title and the keywords of the industrial revolution were grouped and displayed as a percentage. The linkages between the keywords in the title and the keywords of the industrial revolution also indicate whether the $\mathrm{KKN}$ activities serve as a medium to empower the community to face the era of industrial revolution 4.0.

\section{A. Basic Principles of $K K N$}

\section{LITERATURE REVIEW}

In line with the paradigm shift, according to Sudjarwadi as outlined in the Community Empowerment Service Program (KKN) book for Higher Education in Indonesia [2], KKN is carried out based on the following principles:

a. Integration of Tri Dharma aspects of Higher Education; aspects of education and teaching, and research-based community service are the basis for planning, implementing and evaluating $\mathrm{KKN}$,

b. Preservation of Tri Gatra KKN; KKN is implemented to achieve the development of student personality, community empowerment and institutional development.

c. Empathy-Participatory; $\mathrm{KKN}$ is implemented to mobilize the community in development through various activities that can involve, bring everyone to take a part, and foster a sense of community ownership towards development. KKN is conducted interactively and synergistically between students and the community. Consequently, the involvement of both parties in every activity is absolutely necessary. The involvement started from the planning of the field activities, implementation, and funding operations. For this reason, students and managers of KKN must be able to hold a sociocultural approach to the community so that it is more cooperative and participatory,

d. Interdisciplinary; KKN is conducted by students from various disciplines within the university and the implementation is coordinated by Reasearch and Community Service Office (LPPM). In its operations students develop mechanisms of mindset and interdisciplinary work patterns to solve the problems that exist in the location of KKN,

e. Comprehensive-Complementative and broad dimension; KKN functions as a binding, summarizing, enhancing and supplementing the existing curriculum. Thus, it is expected that students participating in KKN are able to actualize themselves professionally and proportionally,

f. Realistic-Pragmatic; planned program activities basically rely on real problems and needs in the field, can be implemented in accordance with the carrying capacity of resources available in the field, and provide benefits to the community, both in the short term and long term, g. Environmental development; KKN is implemented to preserve and develop the physical and social environment for the common good.

Based on these principles, it is hoped that students participating in KKN will be able to identify existing problems in the community and find solutions according to their resources. With hope, the community will be able to be self-sufficient, self-managed and self-sufficient in development.

\section{B. Purpose and Target of KKN}

\section{The purpose}

The objectives of the KKN implementation are:

a. to increase student empathy and care.

b. to implement science and technology applied in a teamwork and interdisciplinary manner.

c. to instill personality values: - Nationalism and the soul of Pancasila. - Tenacity, work ethic and responsibility. - Independence, leadership and entrepreneurship.

d. to increase national competitiveness.

e. to instill the soul of researchers - Exploratory and analysis.

f. to encourage learning community and learning society.

2. Targets

Basically KKN activities are directed at 3 targets, namely: a. Students

1. to deepen understanding, appreciation, and experience of students about: a. Interdisciplinary and cross-sectoral ways of thinking and working. $b$. The usefulness of educational and research outcomes for development in general and rural development in particular. c. Difficulties faced by the community in development as well as the overall context of development problems in regional development.

2. to mature students' minds in every study and problem solving that exists in the community in a scientific pragmatic way.

3. to form attitudes and feelings of love, social care, and responsibility of students towards the progress of society.

4. to provide skills to students to carry out development and development programs.

5. to ostere students to become innovators, motivators, and problem solvers.

6. to provide experience and skills to students as development cadres.

b. Society (and Government)

1. to get the help of the thoughts and energy to plan and implement development programs.

2. to improve the ability to think, behave and act to fit the development program.

3. to obtain the reforms needed in development in the area.

4. to form development cadres in the community so that sustainable development is guaranteed.

c. College

1. Higher education is more focused in developing knowledge and knowledge to students, with feedback as a result of the integration of students 
The $1^{\text {st }}$ International Conference on Global Development - ICODEV

November $19^{\text {th }}, 2019$, Rectorate Building, ITS Campus, Sukolilo, Surabaya, Indonesia

with the community. Thus, the university curriculum can be adjusted to the demands of development. Teachers obtain various cases that can be used as examples in the education process.

2. Higher education can establish cooperation with government agencies or other departments in carrying out the development and development of science and technology.

3. Higher education can develop science and technology which is more useful in the management and resolution of various development problems.

\section{Thematic KKN}

Thematic KKN is a student community service program whose orientation is focused on certain fields in accordance with social problems and the direction of development policies organized by certain regional governments (Regency / City) [1]. Thematic KKN based on Problem Solving to solve problems with certain themes so that students' activities are focused on overcoming certain problems and achieving certain targets.

Characteristics of thematic KKN:

1 . The activity program is designed thematic, institutionalized, sustainable and competency-based

2. Reflect the complexity of the problem and the direction of government development policy

3. Implemented by students, Field Supervisors, and the community

4. Implemented limited time, efficient, effective by prioritizing academic interests and community interests.

\section{ITS Thematic KKN}

In accordance with the ITS KKN Guidebook [3], Institut Technologi Sepuluh November (ITS) Surabaya seeks to contribute to the international and national world. The ongoing national contribution is a contribution of scientific thinking related to the thinking of the Indonesian people. So that the community can benefit from the existence of ITS Campus. In addition to producing an unpretentious form of benefits in the form of teaching and learning activities, there are also Community Service activities (KKN) called Thematic KKN. KKN is chosen by ITS to involve lecturers and students as a "motor solution" to problems in society. This thematic KKN focuses on 'capacity building' which is to educate the public with knowledge and skills.

Students are one of the social groups in a global community. Privileges that students have cannot be measured in terms of material, but in terms of their insight and intellect. Students always try to think ideally and rationally in facing the future of the nation. Thus, the community and students are elements that are expected to think long, and be wise in facing the global problems. The theory possessed by students in education in tertiary institutions and community life experiences need to be harmonized in order to achieve the goals of a more developed nation. Therefore, it is very necessary to have KKN activity, which aims to bring students to understand the realities that develop in society. Students' interdisciplinary or multidisciplinary horizons can broaden the horizons of community thought.

\section{Purpose of ITS Thematic KKN}

a. Educating the people, especially the city of Surabaya

b. Changing people's behavior to be responsive to technology

c. Increasing social sensitivity and social awareness in working with the community and the environment to make the most of the potential possessed by students, lecturers, and ITS institutions.

d. Able to implement technology to solve problems in society.

\section{Benefits of ITS Thematic KKN}

a. For ITS Academicians:

- To have empathy in community groups

- To have a teamwork and interdisciplinary spirit in applying science and technology and creativity

- To sharpen social skills in interacting off campus with community groups

b. For the Community, community has high competitiveness in applying technology to improve welfare.

\section{E. Model of ITS Thematic KKN activities}

ITS Thematic KKN has the following model:

1. Model Activity A

This activity teaches Open Source Technology (IT Training) on KKN objects. The Open Source activities can be:

a. Custome Management System (CMS) technology to create websites using wordpress.

b. Mobile Applications: Camscanner, Kahoot !, Zipgrade, Cloud storage technology, Collaboration Work, Online Questinnaire, Photo / Video graphics, Online Meeting, google calendar and so on.

\section{Model Activity B}

This activity is related to problems and solutions that are realized in the form of proposals presented using the concept of log frames. Problems raised can include social, economic and technological aspects.

\section{Model C Activity}

Model $\mathrm{C}$ activities are carried out in the form of teaching and learning processes in formal schools at the elementary, junior and senior high school levels to provide motivation, sharing, etc., according to the KKN objects. The material provided, in addition to the core material at school can also be in the form of study programs at ITS that are interesting for students to study. Teaching can be carried out in the room (in the classroom) or outside the classroom.

\section{Model Activity D}

Model D activities are teaching about knowledge / skills related to the scholarship of study programs and/or creativity that are tailored to the needs of the KKN objects. Examples of Model D activities:

a. Two-wheeled vehicle repairs carried out by Mechanical Engineering students

b. Cell phone repair by Electrical Engineering students

c. Marketing by Business Management students 
d. Design / use of simple design software by Product Design students, Visual Communication Design, Architects.

e. Training on making drinks, food, cakes by all ITS students who have abilities in that field.

f. Other creativity activities.

\section{F. Industrial Revolution 4.0}

The reality of poverty and inequality in rural areas emphasizes the importance of building inclusive development policies in order to eliminate obstacles that have been faced by the poor - the majority of which are in rural areas - to improve their social welfare. The terminology of inclusive development is not limited to economic aspects but it is broader to provide access to all elements of society in enjoying the results of development, including basic infrastructure and services. According to ADB (2010) [4], several indicators of inclusive development include (i) the rate of economic growth, productive business fields, and economic infrastructure; (ii) income distribution, poverty reduction, and equality of access and opportunity; (iii) enhancing the capability of human resources; and (iv) social protection.

The inclusive development paradigm is a reaction to the development paradigm that is based on economic growth. In the growth paradigm, high economic growth is believed to be able to encourage income distribution and continue to reduce poverty (trickle down effect). In its implementation, in many developing countries there are symptoms of increasing absolute poverty, unequal distribution of income, and unemployment despite stable economic growth [5]. Indonesia experienced the failure of the trickle down effect, following the monetary crisis in 1997.

After the monetary crisis, awareness emerged that economic equality must be pursued in such a way through the formulation of concrete, down-to-earth programs by prioritizing social welfare approaches in development [6]. This concept was later called inclusive development. The meaning of inclusive is used as an approach to build and develop an environment that is increasingly open and includes everyone, including those who have been marginalized. Thus, the key to inclusive development lies in the proactive role of the government to carry out welfare development programs in particular overcoming poverty and social inequality and the active participation of the community as subjects of development as well as government partners in carrying out these programs.

The importance of inclusive development in an effort to address the challenges of social welfare development, especially in alleviating poverty and inequality, has increasingly found its contextuality with the presence of the industrial revolution 4.0. What is meant by industry 4.0 is a work situation where manufacturing is digitally connected supported by four elements, namely the internet of things, big data, cloud computing, and artificial intelligence. Digitalisation also penetrated other industries. Production roles that have been carried out by human labor in the industrial era 4.0 will be replaced by digital programs so that many employment sectors are lost.
Faced with the challenges and needs of building sustainable community resilience in the Industrial 4.0 era, efforts need to be made to present capable institutions and competent human resources, especially all Academic Community Members in Higher Education, as part of Indonesia's development pillars, are expected to play a role obviously participate actively in building national identity. With the predicate of intellectual or intellectual, the educated are expected to be able to take a proactive role in the momentum of the industrial revolution 4.0.

Industrial Revolution 4.0 is characterized by some features, among others are the advanced digitalization and integration of industrial manufacturing and logistics processes, and the use of the internet and "smart" objects (machines and products) and merging the physical and virtual worlds by the adoption of information and communications technology (ICT) [7]. Industrial Revolution 4.0 are proposed with envisioned potential benefits such as shorter operation cycle times, quick delivery times, faster time to market of new products and services, improved quality, and product / service customization, stronger consumer involvement and loyalty [7].

Industrial Revolution 4.0 is based on the use of cyberphysical systems (CPS) production and heterogeneous data and knowledge integration, and its main features are: digitization, automation, optimization, customization, and adaptation of production; human machine interaction (HMI); value-added services and businesses, and automatic data exchange and communication [8].

From the description above it can be understood that the industrial revolution 4.0 has several keywords, including the internet or the internet of things, big data, cloud computing, and artificial intelligence, adoption of information and communications technology (ICT), digitization, automation, human machine interaction (HMI).

\section{G. Indonesian society faces the Industrial Revolution}

Entering the industrial revolution 4.0, is not only related to the readiness of technology, but also the readiness of the people to deal with it. The former Indonesian Minister of Research, Technology and Higher Education, Mohamad Nasir said to face the industrial revolution 4.0 , the community must start by having ' 30 ' which is open mind, open heart, and open willing so that future challenges can be overcome properly[9]. In the current percentage of Indonesian workers, he said, 42\% are in the labor force with low education, but the percentage will continue to decline, meaning that graduate education is starting to change and become better.

As for the demographic bonus, according to him, when not utilized properly, it will be disastrous. Therefore, he emphasized that increasing HR competencies is very important. "Therefore, education must be suitable for industry, so that the nation's competitiveness increases, besides of course the technology readiness level must be increased. If it's low, innovation is low too. " Mohamad Nasir also said that students were the main players in facing the challenges of the Industrial Revolution 4.0. Therefore, students must develop their potential to the 
The $1^{\text {st }}$ International Conference on Global Development - ICODEV

November $19^{\text {th }}, 2019$, Rectorate Building, ITS Campus, Sukolilo, Surabaya, Indonesia

maximum extent possible while studying on campus, not only in academics but also in creativity and innovation.

The minister encourages students to build a high level of trust and a spirit of competition to compete not only at the national level but also at the global level. In addition to academic degrees, there are four things students must have to fight in the era of the industrial revolution 4.0 namely competence to interact with various cultures, social skills, new literacy (data, human technology) and lifelong learning (lifelong learning)

In addition to teaching and research, Tri Darma Pendidikan demands Academic Community Members to do community service. Community service programs such as KKN are very important to be intensified. However, the campus can also begin to develop concepts that are sustainable for community development, especially in rural areas and build an academic spirit to produce reliable social workers. The campus is also expected to provide a curriculum that fosters an inclusive character, which is to print students who are sensitive to social welfare issues in society.

\section{RESULTS AND DISCUSSION}

Based on Table 1, the majority of ITS Thematic KKN is activity A model that is strongly related to the use of the internet and information and ommunication technology with 28 titles or $45.2 \%$. TABLE 1.

PERCENTAGE OF KKN ACTIVITY TITLE ACCORDING TO KKN ACTIVITY MODEL

\begin{tabular}{lcc}
\hline \hline ITS KKN Activity Model & $\begin{array}{l}\text { Number of } \\
\text { Title }\end{array}$ & Percentage \\
\hline $\begin{array}{l}\text { Model A (ICT and intenet based } \\
\text { activities) }\end{array}$ & 28 & $45.2 \%$ \\
$\begin{array}{l}\text { Model B (social, economical and } \\
\text { technology) }\end{array}$ & 15 & $24.2 \%$ \\
Model C (teaching and learning) & - & - \\
Model D (skill-related training) & 19 & $30.6 \%$ \\
Total & $\mathbf{6 2}$ & $\mathbf{1 0 0 \%}$ \\
\hline \hline
\end{tabular}

The next position is the activity model $\mathrm{D}$ activity which is related to students' related skills by $30.6 \%$ or 19 titles. The next is the model of activity B which is related to social, economic and technological activities with 15 titles or $24.2 \%$. Model $\mathrm{C}$ in the form of teaching and learning activities do not have data because there is no single activity title that is specifically related to teaching and learning activities.

From the description above it can be understood that the activities which are closely related to information and communication technology and the internet are the KKN activities that are most in demand by ITS students. These activities are also very closely related to the key words of the industrial revolution. How many thematic KKN titles related to the keywords of the industrial revolution can be seen in Table 2.

Table 2 shows the number of ITS Thematic KKN titles related to the keywords of the industrial revolution 4.0. From these data it can be seen that $53.6 \%$ or 15 thematic KKN titles are related to the keywords value-added services and business, which are related to on-line business, e-commerce, online marketing and so on.
TABLE 2

TITLE OF ITS KKN ACTIVITIES RELATED TO KEY WORDS OF THE INDUSTRIAL REVOLUTION

\begin{tabular}{|c|c|c|}
\hline $\begin{array}{l}\text { Keywords related to the industrial } \\
\text { revolution } 4.0\end{array}$ & $\begin{array}{l}\text { Number } \\
\text { of Title }\end{array}$ & Percentages \\
\hline 1. Internet atau internet of things & 1 & $3.6 \%$ \\
\hline Big data & - & \\
\hline Cloud computing & 1 & $3.6 \%$ \\
\hline Artificial intelligence & - & \\
\hline $\begin{array}{l}\text { 5. Information and } \\
\text { communications technology } \\
\text { (ICT }\end{array}$ & 4 & $14.3 \%$ \\
\hline Digitization & 3 & $10.7 \%$ \\
\hline 7. Automation & - & \\
\hline $\begin{array}{l}\text { 8. Human machine interaction } \\
\text { (HMI) }\end{array}$ & - & \\
\hline $\begin{array}{l}\text { 9. Value-added services and } \\
\text { businesses }\end{array}$ & 15 & $53.6 \%$ \\
\hline $\begin{array}{l}\text { Automatic data exchange and } \\
\text { communication }\end{array}$ & 4 & $14.3 \%$ \\
\hline Total & 28 & \\
\hline
\end{tabular}

The second is related to information and communication technology and automatic data exchange and communication, each with 4 titles or $14.3 \%$. It includes information and communication technology such as IT training and basic applications such as microsof office. The examples of atomatic data exchange and communication are training in the use of applications such as the Puntadewa Surabaya residence application and applications for learning.

The third position is the title associated with digitalization of 3 titles or $10.7 \%$. while the fourth is the title associated with the keyword internet or internet of things and cloud computing, each of which is 1 title or $3.6 \%$.

\section{CONCLUSIONS}

From the explanation above, it can be concluded that the ITS Thematic Community Service Program/KKN activities carried out by ITS students can help the community to be ready to face the industrial revolution 4.0. 28 titles from total of 62 titles or $45.2 \%$ of the ITS Thematic KKN titles are model A related to Information and Communication Technology (ICT) and internet-based activities which are the main and most important elements of the industrial revolution 4.0. The 28 titles are closely related to key words of the industrial revolution 4.0 such as on-line business, e-commerce, online marketing and so on $(53.6 \%)$. Next is the titles associated with information and communication technology and atomatic data exchange and communication, each with 4 titles or $14.3 \%$.

\section{REFERENCE}

[1] Sepenggal info, "Perbedaan KKN-Tematik dan KKN-POSDAYA," sepenggal.info, 2015. [Online]. Available: https://sepenggal.info/perbedaan-kkn-tematik-dan-kkn-posdaya/.

[2] Sudjarwadi, Buku Pedoman Kuliah Kerja Nyata Pembelajaran Pemberdayaan Masyarakat (KKN PPM) Perguruan Tinggi di Indonesia. Jakarta: Direktorat Penelitian dan Pengabdian Kepada Masyarakat, Direktorat Jenderal Pendidikan Tinggi Departemen Pendidikan Nasional, 2007.

[3] A. Zubaydi, Buku Panduan Kuliah Kerja Nyata (KKN) Tematik. Surabaya: Direktorat Akademik Institut Teknologi Sepuluh Nopember Surabaya, 2018.

[4] ADB, "Kebijakan Komunikasi Publik Bank Pembangunan Asia." 
The $1^{\text {st }}$ International Conference on Global Development - ICODEV

November $19^{\text {th }}, 2019$, Rectorate Building, ITS Campus, Sukolilo, Surabaya, Indonesia

ADB, 2010.

[5] H. Warsilah, "Pembangunan Inklusif sebagai Upaya Mereduksi Ekslusi Sosial Perkotaan: Kasus Kelompok Marjinal di Kampung Semanggi, Solo, Jawa Tengah,” J. Masy. dan Budaya, vol. 17, no. 2, pp. 207-232, 2015.

[6] A. G. Kartasasmita, "Membangun Masyarakat Desa melalui Kebijakan Pembangunan yang Inklusif di Era Industri 4.0," Jakarta, 2019.

[7] L. Miguel, "Industry 4.0 and the digital society: concepts, dimensions and envisioned benefits," in The 12th International Conference on Business Excellence 2018, 2018, pp. 386-397.

[8] I. Posada, J. Toro, C., Barandiaran, I., Oyarzun, D., Stricker, D., de Amicis, R. and Vallarino, "Visual computing as a key enabling technology for industrie 4.0 and industrial internet.," IEEE Comput. Graph. Appl., vol. 35, no. 2, pp. 26-40, 2015.

[9] N. F. A. B. Baqiroh, "Menristekdikti: Hadapi Revolusi 4.0, Masyarakat Harus Siapkan '3O,”’ Bisnis.com, 2018. [Online]. Available:

https://kabar24.bisnis.com/read/20180915/255/838608/menristekdi kti-hadapi-revolusi-4.0-masyarakat-harus-siapkan-3o. 